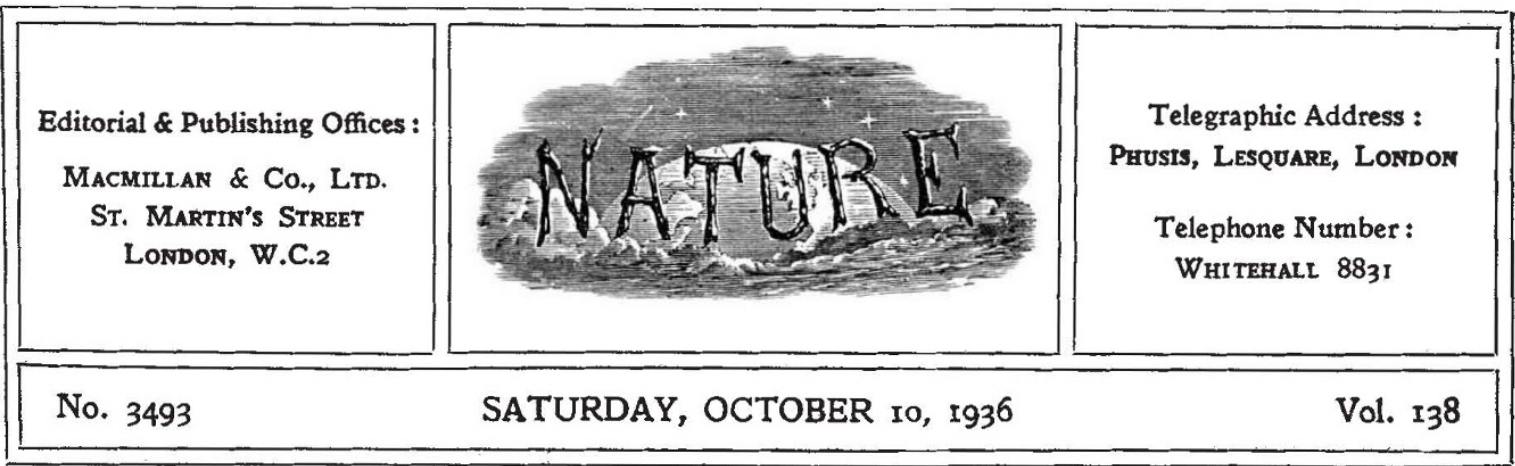

\title{
The Future in Education
}

SIR RICHARD LIVINGSTONE'S presidential $S$ address to Section L (Educational Science) of the British Association at the recent Blackpool meeting is one which should receive attention from all who are interested in educational purposes and scope. His views concerning some of our fundamental ideas on education must either be accepted -in which case far-reaching changes of thought and practice are necessary-or they must be proved to be mistaken. For our part, we believe he has put his fingers upon weaknesses which must be remedied both from the material point of view of value for educational expenditure, and from the philosophical point of view which would have education fit the masses for the tasks-and possible struggles-which lie ahead.

Sir Richard described the three-fold function of man : to make a livelihood, to be a citizen and to be a man; and he asked whether, despite our achievements since the education Acts of 1870 onwards, through which the main lines of our primary, secondary, technical and university organization were laid down, we can now claim to be an educated nation. Does our system make men and citizens? If the majority of an electorate are incapable of benefiting from what are called humanistic studies, "we must either abandon democracy or resign ourselves to be governed by an electorate which can never know what a state should be. Ancient tradition and political instinct may preserve such a democracy from disaster, but not only will its stability be precarious, but its political and spiritual life will be poor. The bad film and the betting news will be its relaxation; the bad press its literature, passion, prejudice, the catchword and the slogan will be its masters".
If the education of children ceased at fourteen years of age in the past, it mattered perhaps less than it does now. Education for leisure would have little purpose if the working man lacked leisure. "Fifty years ago the employment of leisure was no problem for any but the well-to-do who mostly wasted it. To-day it is becoming a commonplace in education." At fourteen years of age a child has made a beginning in many subjects: he has received a training which enables him to use opportunity for learning more: but he knows nothing of the forces affecting his country which, as a voter, he will help to determine. Economic and political theories are outside his range; his knowledge of literature is small, his knowledge of science smaller.

Ordinarily, the answer to such criticisms is that the school-leaving age should be raised. But it is here that Sir Richard Livingstone's first challenge appears. He does not argue against raising that age, but he says plainly that it will not, in itself, solve our problems. He makes the telling point that education must be adjusted not only to the natural capacities of the pupil, but also to the stage of development his brain has reached. "At the age of 14 or 15 the mind cannot cope with, if it can conceive, the subjects which compose a liberal education and are vital to the citizen." When, therefore, the Hadow Report spoke of giving a "liberal and humane" education through the schools it proposed, it was using "one of those phrases sounding seductive, but untrue, into which all of us are at times betrayed. The thing is impossible because a humane and liberal education includes subjects which a fifteen-year-old is not sufficiently adult to grasp". In short, maturity 
of mind is essential to humanistic studies for which full understanding demands experience of life.

What, then, is the solution? Sir Richard is emphatic that it does not lie in secondary education "about which this age is over-credulous. . . . We must keep our faith in it, but temper it with scepticism", since it is only one part of a great picture from which, to see it as a whole, we must stand back a little.

If the value of raising the school-leaving age is moral and economic rather than intellectual, and if secondary education is insufficient, where must we turn? One direction must be that of adult education. "In every point except the economic one, adult education has the advantage over secondary education. . . . It is given to students who desire it, who have the mental development to receive it, and have the experience of life to value and interpret it."

In this connexion it is inevitable that we should think of the Workers' Educational Association. Sir Richard Livingstone rightly emphasized the value of its work, but here, too, he rightly challenges complacency and indicates weaknesses. Our population is some $43,000,000$. In 1935 there were 59,000 students in W.E.A. classes (at a cup-tie final there are twice that number !). The W.E.A. has therefore left untouched the vast mass of the population, although it has provided for their intelligentsia. Such studies as it has provided must continue, but for the ordinary man a different treatment is needed. Subjects must be brought into connexion with his outlook, his interests and his mind. To do this, Sir Richard sees that new methods must be sought, and he does not hesitate to say that "one of the reasons perhaps why so little progress has been made in adult education is that teachers have mostly been men with honours degrees who have brought to their work the methods and outlook of their own education".

There remain still the problems of post-primary education, and here Sir Richard's suggestions can be said to go back to the ideas adumbrated when the Education Act of 1918 was in preparation. Briefly, "the ideal plan might be for everyone to leave school at 15 and pass into a system where a part of the week was allotted to school, part to earning the living in some practical occupation, the proportions of each varying with the intellectual abilities of the pupil and the demands of the subjects he was studying". For our part we believe that such a system of part-time education would achieve far more than a system which merely raises the school-leaving age with the view of lengthening the period of full-time education. Like Sir Richard, we would not argue against raising the school-leaving age : but, whether that age be fourteen or fifteen or even more, we believe that an education such as Sir Richard has suggested will be best achieved if the pupil has some knowledge of and contact with the practical world. If education is a preparation for life, it cannot neglect the world in which we live. That world rests upon industrial and commercial foundations, and it is only when a pupil has had some contact with the realities found in practical occupations that he will appreciate the value and purpose of education. In Sir Richard's words, "theory will be illuminated by practice and practice by theory. At present the two are nearly always divorced. We lead a life of action without thought; or we think in a vacuum without contact with the realities and problems of the world. Neither form of isolation is satisfactory". What happens at present is that, on reaching the school-leaving age, the great mass of pupils are expelled abruptly from educational influence: and, without it, the real significance of democratic rights and duties is lost and the possibilities of a wide adult education almost hopelessly diminished.

A scheme of part-time education may, of course, be impossible for all pupils, but even those who follow the usual path to the university might avoid suffering from ignorance of life if a layer of practical experience could be imposed between school and university. The 'sandwich system' followed by engineers is an example.

Wisely, in our view, Sir Richard Livingstone did not attempt full and detailed programmes: that, as he said, would be a fitting task for the Board of Education's Consultative Committee. But, whatever the details may be, we believe he has made out a case for serious change, and his case must either be answered or accepted. His challenge to our present system cannot be denied unless the terrible implication of the following passage can also be disputed: "At present life is so arranged that most of us do our thinking in youth at an age when we are not best fitted for it, and having left the university think, systematically, no more. What wonder that middle life finds so many men unaware of recent progress in their own field, unapt for new experiments and ideas, deeply embedded in their rut, while progress waits impatiently for their death and the arrival of the next generation!" 